\section{God som lesebok}

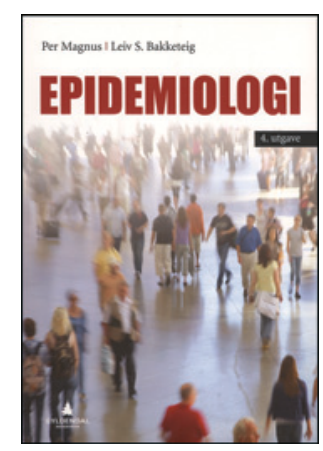

Per Magnus, Leiv S. Bakketeig

Epidemiologi

4. utg. 208 s, tab, ill. Oslo: Gyldendal

Akademisk, 2013. Pris NOK 325

ISBN 978-82-05-42238-4
Da den første utgaven av Epidemiologi kom, var tidspunktet (1993) det best tenkelige: Bare et fătall personer kunne stave ordet og uttale det rett, og klinikere flest var skråsikre på at dette var et fag forbeholdt smittsomme sykdommer. Andre tegn på at en «ny tid» var i emning, var opprettelsen av en egen avdeling for epidemiologi ved daværende SIFF (Statens institutt for folkehelse) og et eget program til støtte for utviklingen av faget under daværende NAVF (Norges allmennvitenskapelige forskningsråd). De to forfatterne var allerede på dette tidspunktet toneangivende parhester ved avdeling for epidemiologi. All undervisning til da var preget av fagets engelskspråklige bakgrunn, og endelig kom en liten, men presis og hendig utgivelse på norsk. Det fikk positive konsekvenser for undervisningen av leger og annet helsepersonell.

Dette er fjerde utgave. Den er vesentlig større og mer omfattende enn den første, som var i lommeformat og med en tekst som var knapt halvparten så lang. Likevel er det lett å kjenne igjen strukturen, denne gangen er boken delt i tre: grunnleggende prinsipper, noen viktige epidemiologiske metoder og epidemiologi i praksis.

I forordet til denne utgaven skriver forfatterne blant annet: «Selv om denne utgaven av boken er mer omfattende enn tidligere, berører vi bare overflaten av mange viktige temaer ... vårt hovedmål er å belyse grunnprinsippene». Det er også hovedinntrykket som sitter igjen. For all del, den er systematisk oppbygd og velskrevet, innholdet er lett gjenkjennelig og ikke til å misforstå. Et unntak er den formidable trykkfeilen under omtalen av oddsratio (s. 75). Som førstegangsleser ville jeg revet meg fortvilt $\mathrm{i}$ håret for å komme til rett svar her.

I dette ligger også den største utfordringen, for hvem er leseren? På forlagets hjemmesider er denne utgivelsen plassert i kategorien «helse- og sosialfag - tverrfaglige emner». Med erfaring fra egen undervisning drister jeg meg til å si at uten forkunnskaper kan denne boken lett bli krevende for studenter på både bachelor- og masternivå. Det samme gjelder medisinstudenter, som også har behov for en innføringsbok i faget. Det nyeste tilskuddet er kapitlet om genetisk epidemiologi, som er behandlet på en god måte. Problemet her er at utviklingen raser av gårde, slik at den fulle betydningen av blant annet helgenomsekvensering trolig vil få mer plass $i$ en senere runde.

Forfatterne berømmes for eksemplene de bruker for å illustrere deskriptive og analytiske metoder og de sentrale feilkildene, men bruken av greske symboler kan virke fremmed, og kapitlet om de statistiske metodene kan skremme studenter med et anstrengt forhold til tall. Det er for eksempel ikke intuitivt å ta inn over seg at variansen til en oddsratio er antilogaritmen (anti-ln) til summen av de inverse tallverdiene av innholdet i 2 x 2-tabellen (s. 69). Trøsten er at det gir mening til slutt, men for flere ligger den trolig et godt stykke frem.

Mest av alt savner jeg at alle typer studenter blir utfordret i større grad, og på en helt annen måte. Med det mener jeg flere eksempler fra den «virkelige verden», men først og fremst oppgaver de kan settes til å løse på egen hånd, helst flere sammen. I likhet med andre lærebøker (1) ville det hevet utbyttet av denne boken flere hakk.

\section{Geir Wenberg Jacobsen}

Professor, Norges teknisk-naturvitenskapelige universitet

\section{Litteratur}

1. Jacobsen GW. Endelig en lærebok i epidemiologi. Tidsskr Nor Legeforen 2012; 132: 1263 . 